Ferit Kula*

UDK 336.748

Alper Aslan*

Mete Feridun*

\title{
PURCHASING POWER PARITY IN MENA REVISITED: EMPIRICAL EVIDENCE IN THE PRESENCE OF ENDOGENOUSLY DETERMINED BREAK POINTS
}

\begin{abstract}
This paper re-examines the Purchasing Power Parity hypothesis in which the endogenously determined break points are incorporated in 13 major MENA countries by using official and black market exchange rates data over 1970-1998. We utilize Lagrange Multiplier unit root test that endogenously determines structural breaks in level. We find evidence of PPP for eight of the thirteen countries at the $10 \%$ level or better. We also construct the half lives to investigate the persistence of deviations from PPP. The point estimates of the half lives for both OREX and BMREX in the seven countries are lower than range of the consensus of 3-5 years in the literature. ${ }^{1}$
\end{abstract}

Keywords: PPP, Black Market Exchange Rates.

JEL Code: $E 24$

\section{INTRODUCTION}

Purchasing power parity (PPP) has been one of the most enduring concepts in international economics. The theory, which is a generalization of the law of one price, supposes that all goods are identical and transportation costs and trade barriers are very low in both countries. The absolute version of the theory asserts that under these conditions, the same basket of goods and services should cost the same when expressed in terms of the same currency.

On the other hand relative PPP is said to hold when the rate of depreciation of one currency relative to another matches the difference in aggregate price inflation between the two countries concerned. If the nominal exchange rate is defined simply as the price of one currency in terms of another, then the real exchange rate is the nominal exchange rate adjusted for relative national price level differences (Sarno and Taylor, 2002).

In MENA countries covered in the present study, black market exchange rates have a long tradition. The purpose of this study is to test the validity of the PPP in thirteen MENA countries using both BMREX and OREX by time series unit root tests with breaks. We also construct the half lives to investigate the persistence of shocks to the OREX and BMREX. The study differs from earlier studies which take in to account MENA countries in this way.

\footnotetext{
* Ferit KULA Department of Economics, Faculty of Economics and Administrative Sciences Erciyes University Kayseri, Turkey. E-mail: kulaf@erciyes.edu.tr

* Alper ASLAN Department of Economics, Faculty of Economics and Administrative Sciences Nevsehir University Nevsehir, Turkey E-mail: alperleo@gmail.com

* Mete FERIDUN Department of Banking and Finance Faculty of Business and Economics Eastern

Mediterranean University Gazi Magosa, Mersin 10 Turkey E-mail: mete.feridun@emu.edu.tr
} 
The black market and official exchange rates data are taken from the study of Reinhart and Rogoff (2004). Price levels are defined as the logarithm of the price ratio generated by the each country's consumer price index (CPI) divided by the US CPI (IFS line 64) and taken from the International Monetary Fund's International Financial Statistics (IMF-IFS) database. Due to the lack of consistent data on the CPI index for some countries before 1970 and unavailability of data beyond 1998 for black market, the data spans from 1970-1998. The 13 MENA countries considered in this study are Algeria, Egypt, Iran, Iraq, Israel, Jordan, Lebanon, Libya, Morocco, Saudi Arabia, Syria, Tunisia and Turkey.

The rest of the paper is organized as follows: The next section is devoted to describe the literature. Section 3 presents the basic model and data. Section 4 describes the LM unit root methodology and section 5 presents the conclusion of the paper.

\section{LITERATURE REVIEW}

There exists a rich literature on the validity of the PPP hypothesis. Despite a vast empirical literature, many questions remain regarding the validity of PPP. The validity of the PPP has been extensively tested, especially for developed countries and focused on official exchange rates. In general, PPP is a valid long-run equilibrium condition at least in industrialized economies (see the survey of Froot and Rogoff, 1995; Sarno and Taylor, 2002; Sarno 2003). On the other hand, empirical evidence on the validity of long-run PPP for developing countries is rather mixed (see, for example, Telatar and Kazdagl1, 1998; Bahmani-Oskooee and Mirzai, 2000; Luintel, 2000; Basher and Mohsin, 2004). On the other hand, a number of studies have documented evidence showing persistent deviations from PPP. Studies by Roll (1979), Frankel (1981, 1986), Adler and Lenmann (1983), Hakkio (1986), and Taylor (1988) fail to reject the hypothesis that real exchange rate follows a random walk. Studies, by Frankel and Mussa (1985) Edwards (1989), Roll (1979), and Pippenger (1982) reveal that deviations from PPP follow a random walk process which implies that the deviations from PPP are cumulative and permanent such that PPP does not hold. Studies by Abouf and Jorian (1990) find evidence that verifies long-run PPP based on multivariate unit root tests performed on first differences rather than levels. Cheung and Lai (1993) and Chen (1995) find some fragmented support for PPP based on cointegration analysis. Lothian and Taylor (1997), based on panel data, verified long-run PPP through use of multivariate unit root tests. Cheung and Lai (1998) find evidence in favor of mean reversion using fractional cointegration. In short, empirical results from the past studies have been mixed and conflicting. Most studies concluded that PPP does not hold. Mark (1990) did not reject the null of a unit root and the null of no-cointegration. On the contrary, Chen (1995) who used monthly data from five European countries over the period 1973:4-1990:12 concluded that the PPP hypothesis is upheld. Feridun (2005) finds evidence that does not favor mean reversion in the log real exchange rates for the exchange rates US Dollar-French Franc, US Dollar- German Mark, and US Dollar-Great Britain Pound for both monthly and quarterly observations. Hence, the study fails to verify PPP based on these three exchange rates. Hung and Jan (2002) show that the PPP does not hold for most Asian markets. Montiel (1997); Baharaumshah and Ariff (1997); and Weliwita (1998) show non- stationary real exchange rate. Froot and Rogoff (1995); and Rogoff (1996) show a slow parity reversion. Kuo and Mikkola (1999); Glen (1992); and Lothian and Taylor (1996) reject the random walk hypothesis in the real exchange rate. Meese and Rogoff (1983) show a contrary result to the theory of PPP; they conclude that the real exchange rate follows a random walk, implying that time series can fluctuate without bound. Some studies focus on the development of econometric models based on economic 
fundamentals. Mark (1995), MacDonald (1996), and Taylor and Peel (2000) attribute the predominant source of real exchange rate fluctuations to the effect of real disturbances.

Although black market exchange rates (BMREX) play such a key role in emerging market economies, there is very few papers in the PPP literature use this major source of information to investigate the long run PPP hypothesis. Pioneering study of Age'nor and Taylor (1993), Baghestani (1997), Phylaktis and Girardin (2001) and Aslan et al. (2009) examined for 19 developing countries, India, China and Turkey, respectively. Phylaktis and Kassimatis (1994) and Luintel (2000) focused on the experience of seven countries in the Pacific Basin region, while Diamandis (2003) analyzed four Latin-American countries and Cerrato and Sarantis (2007) examined 34 emerging countries. Studies that have used the black market rates have generally supported PPP more than those that have used official rates (Bahmani-Oskooee and Goswami, 2005).

There are few studies (Bahmani-Oskooee, 1998; Narayan and Prasad, 2005) on the exchange rates of MENA countries as a group. One of them is Narayan and Prasad (2005) who considered PPP for 11 Middle Eastern countries using a number of tests: the one break test unit root, the two breaks unit root test, and the panel lagrange multiplier (LM) unit root test with structural breaks. The main finding from univariate tests is that there is evidence for PPP in only seven countries (Lebanon, Saudi Arabia, Egypt, Iran, Syria, Tunisia and Sudan). However, when the panel LM test is applied with two structural breaks, strong evidence is found in favor of PPP for the Middle Eastern countries.

\section{BASIC MODEL AND DATA}

$$
R E R=N E R \frac{P^{*}}{P}
$$

where RER is the real exchange rate, NER is the nominal exchange rate and $\mathrm{P}^{*}$ and $\mathrm{P}$ are the foreign and domestic prices, respectively. In logarithmic form, the real exchange rate can be represented by

$$
\log (R E R)=\log (N E R)+\log \left(P^{*}\right)-\log (P)
$$

Following equation shows the model of mean reverting real exchange rate

$$
\log (R E R)_{t}=\alpha+\beta \log (R E R)_{t-1}+\varepsilon_{t}
$$

where $\alpha$ and $\varepsilon$ are constant and error term respectively. PPP suggest that real exchange rate series should be stationary. If real exchange rate is stationary this exhibit that any percentage changes in the price level between two countries would be offset by an equal depreciation/appreciation of the nominal exchange rate. If there is a unit-root in the real exchange rate this implies that shocks to the real exchange rate are permanent and PPP does not exist between two countries

\section{LM UNIT ROOT METHODOLOGY}

The majority of studies on the validity of PPP theory in developing countries have used Augmented Dickey-Fuller (ADF) tests. The ADF statistics have been found to have low power with a short time span. Another limitation of the conventional ADF test is that they do 
not take into account potential structural breaks in the series. Perron (1989) showed that failure to allow for an existing structural break leads to a bias that reduces the ability to reject a false unit root null hypothesis.

This paper applies univariate Lagrange Multiplier (LM) unit root tests with structural breaks proposed by Lee and Strazicich $(2003,2004)$. We utilize the general model (crash model) that allows for up to two breaks in the level of the series. The two break minimum LM unit root can be described as follows. According to the LM (score) principle, a unit root test statistic can be obtained from the following regression:

$$
\Delta Y_{t}=\delta^{\prime} \Delta Z_{t}+\phi \widetilde{S}_{t-1}+\sum_{1}^{k} \gamma_{i} \Delta \widetilde{S}_{t-i}+\varepsilon_{t}
$$

Where $\widetilde{S}_{t}$ de-trended series that $\widetilde{S}_{t}=Y t-\widetilde{\psi}_{x}-Z_{t} \widetilde{\delta}$, for $t=2, \ldots, T . \widetilde{\delta}_{\text {is }}$ a vector of coefficients estimated from the regression of $\Delta Y t$ on $\Delta Z t$ and $\widetilde{\psi}_{x}=Y_{1}-Z_{1} \widetilde{\delta}$, where $Y_{1}$ and $Z_{1}$ firs observations $Y_{t}$ and $Z_{t}$, respectively. $Z_{t}$ is a vector of exogenous variables defined by the data generation process of the series. Crash model includes two breaks in level and is described by $Z_{t}=\left[1, t, D_{1 t}, D_{2 t}\right]$, where $D_{j t}=1$ for $t \geq T_{b j}+1, j=1,2$ and zero otherwise.

The unit root null hypothesis is described by $\phi=0$ (implying a unit root with two breaks), and the LM test statistics are given by:

$$
\tilde{\tau}=\mathrm{t} \text { statistics for the null hypothesis } \phi=0 \text {. }
$$

The minimum LM unit root $\mathrm{t}$-statistic determines the endogenous location of two breaks $\left(\lambda_{j}=T_{b j} / T, j=1,2\right)$. The LM unit root test can endogenously determine the two breaks by utilizing a grid search as follows:

$$
L M t=\inf _{\lambda} \widetilde{\tau}(\lambda)
$$

This methodology presents the following advantages. First, the minimum LM t-statistics allow for breaks under the null and alternative, which avoids the possibility of spurious rejections caused by size distortion. Second, the optimal number of break points and their location together with the degree of augmentation are endogenously and jointly determined.

\section{EMPIRICAL STRATEGY AND RESULTS}

Following Lee and Strazicich (2003), in the beginning, we determine the number of lagged augmentation terms and we start from a maximum of $\mathrm{k}=8$ lagged terms. As such, the procedure looks for the significance of the last augmented term. We then use the $10 \%$ asymptotic normal value of 1.645 on the t-statistic of the last first differenced lagged term. After determining the optimal $\mathrm{k}$ at each combination of two break points, we can determine the breaks where the endogenous two break LM t-test statistic is at a minimum. We examine each possible combination of two break points over the time interval [0.1T, 0.9T] while eliminating the endpoints. Here, $\mathrm{T}$ is the sample size.

We begin with the LM unit root t-statistic with two breaks and examine the significance of the dummy coefficients on the basis of the conventional t-statistics. 
If less than two breaks are significant at $10 \%$ we apply the minimum LM unit root t-statistic with one break proposed by Lee and Strazicich (2004), and if the break is insignificant we employ the LM unit root t-statistic without breaks proposed by Schmidt and Phillips (1992) ${ }^{2}$. We summarize the results in Table $1^{3}$.

Table 1

LM Unit Roots Test Results (break in levels)

\begin{tabular}{|c|c|c|c|c|c|}
\hline Country & OREX & & BMREX & & \\
\hline & $\begin{array}{l}\text { LM } \\
\text { Statistics }\end{array}$ & $\begin{array}{l}\text { Number of break(s) } \\
\text { and location(s) }\end{array}$ & LM Statistics & $\begin{array}{l}\text { Number } \\
\text { break(s) } \\
\text { location(s) }\end{array}$ & $\begin{array}{r}\text { of } \\
\text { and }\end{array}$ \\
\hline Algeria & $-3.170(1)$ & 1990-1993 & $-1.663(0)$ & -------- & \\
\hline Egypt & $-2.946(1)^{*}$ & -------- & $-8.850(6) * * *$ & 1983-1990 & \\
\hline Iran & $-0.893(0)$ & 1992 & $-7.477(8) * * *$ & 1981-1990 & \\
\hline Iraq & $\begin{array}{l}-5.890 \\
(7)^{* * *}\end{array}$ & 1990-1996 & $-2.687(3)$ & 1992-1994 & \\
\hline Israel & $-2.995(6)$ & 1984 & $-2.206(0)$ & --------- & \\
\hline Jordon & $-2.937(5)$ & 19851988 & $-2.419(7)$ & 1985-1988 & \\
\hline Lebanon & $-2.222(2)$ & ------- & $-2.085(2)$ & -------- & \\
\hline Libya & $-2.300(0)$ & --------- & $-2.933(0)^{*}$ & --------- & \\
\hline Morocco & $-2.021(1)$ & --------- & $-3.567(7)^{*}$ & $1985-1987$ & \\
\hline Saudi & -3.891 & -------- & $-2.498(1)$ & ----------- & \\
\hline Arabia & $(7)^{* * *}$ & & & & \\
\hline Syria & $-4.220(7)^{* *}$ & 1986-1994 & $-2.432(7)$ & ----------- & \\
\hline Tunisia & $-3.059(7)$ & 1992-1996 & $-2.839(8)$ & 1989 & \\
\hline Turkey & $-2.925(8)$ & 1983-1986 & $-4.719(6) * * *$ & 19811993 & \\
\hline
\end{tabular}

Notes: The 1,5 and $10 \%$ critical values for the LM unit root t-statistic without breaks are: $-3.63,-3.06$ and -2.77 . The 1,5 and $10 \%$ critical values for the minimum LM unit root t-statistic with one break are: $-4.239,-3.566$ and -3.211 . The 1,5 and $10 \%$ critical values for the minimum LM unit root t-statistic with two breaks are: $-4.545,-3.842$ and $-3.504 .{ }^{*}, * *, * * *$ denote statistical significance at the 10,5 and $1 \%$ levels, respectively. The lag length is reported in parentheses.

Four of the thirteen OREX series (Egypt, Iraq, Saudi Arabia and Syria) reject the unit root null at the $10 \%$ level or better. Rejection of the null hypothesis would imply that this OREX series exhibit mean reverting tendencies. In other words, PPP holds. The examination reveals that two structural breaks in level are significant (t-values significant at 10\%) six OREX series (for Algeria, Iraq, Jordon, Syria, Tunisia and Turkey), while only one structural break is significant in the two countries (Iran and Israel). However, the structural break is not significant for other countries (Egypt, Lebanon, Libya, Morocco and Saudi Arabia).

The results of the unit root tests as shown in Table 1 appear to support that the BMREX series are stationary for the sample of five countries (Egypt, Iran, Libya, Morocco and Turkey). However, the null hypothesis is not rejected for other countries. Table 1 also shows that two structural breaks in level are significant six BMREX series (for Egypt, Iran, Iraq, Jordon, Morocco, and Turkey). A structural break is found to exist in only Tunisia out of 13 countries. It is observed that any structural break is significant for other remaining countries (Algeria,

\footnotetext{
${ }^{2}$ We want to determine if including two breaks instead of one can adversely affect power to reject the null. To check for this possibility, we perform additional tests.

${ }^{3}$ See appendix for more detail.
} 
Israel, Lebanon, Libya, Saudi Arabia and Syria). Overall, we find evidence of PPP for eight of the thirteen countries or $60 \%$ of the sample at the $10 \%$ level or better. The unit root null is rejected for OREX in Iraq, Saudi Arabia and Syria, but not for BMREX, while the unit root null is rejected for BMREX in Iran, Libya, Morocco and Turkey but not for OREX. The PPP holds for both OREX and BMREX in Egypt as only one out of eight cases.

A structural break is found to exist in eight out of thirteen countries for OREX and seven out of thirteen countries for BMREX series, all occurring during the period from 1981 to 1996. This preponderance of break points may reflect policy transformation during this period that lead to large shifts in the exchange rates markets. In addition to exchange rates, the business cycle and political instability might significantly impact price levels in most MENA countries.

Our other one interest in this paper concerns the persistence of shocks to the OREX and BMREX. A measure of persistence typically applied in the literature is the half life, which indicates how long it takes for the impact of a unit shock to dissipate by half.

Table 2 report calculations of the half lives of random shocks to the OREX and BMREX series that are able to reject the null of unit root for the countries based on the Table 1 . Looking at the half life point estimates, we can observe that the half life for the OREX series range minimum from 0.326 years (Saudi Arabia) to maximum 7.436 (Iraq). And it is found that the estimated half lives of adjustments to PPP are 0.374 and 0.689 for Syria and Egypt respectively.

Table 2

Half Lives of OREX and BMREX

\begin{tabular}{|c|c|c|c|c|c|c|}
\hline Country & OREX & & & BMREX & & \\
\hline & $\phi$ & $\begin{array}{l}\text { Half } \\
\text { (years) }\end{array}$ & lives & $\phi$ & $\begin{array}{l}\text { Half } \\
\text { (years) }\end{array}$ & lives \\
\hline Egypt & -0.366 & 0.689 & & -0.562 & 1.202 & \\
\hline Iran & ----- & ----- & & -0.730 & 2.202 & \\
\hline Iraq & -0.911 & 7.436 & & ----- & ----- & \\
\hline Libya & ----- & ----- & & -0.525 & 1.075 & \\
\hline Morocco & ---- & ----- & & -0.380 & 0.716 & \\
\hline $\begin{array}{l}\text { Saudi } \\
\text { Arabia }\end{array}$ & -0.120 & 0.326 & & ----- & ----- & \\
\hline Syria & -0.157 & 0.374 & & ---- & ----- & \\
\hline Turkey & ----- & ----- & & -0.571 & 1.236 & \\
\hline
\end{tabular}

Notes: The reported value for $\phi$ is estimated from Eq. (4) and used to calculate the reported "approximate" half lives, $\ln (0.5) / \ln |\phi|$. 
As reported in Table 2, the estimated half lives indicate the existence of considerable variation in the persistence of BMREX series among countries. But contrary to OREX series (if we neglect Iraq), all are over one year except Morocco (0.716). The point estimates of the half lives for both OREX and BMREX in the seven countries are lower than range of the consensus of 3-5 years in the literature (e.g. Rogoff, 1996). It is important to note that half live for OREX in Egypt is faster than BMREX based estimate.

Table 3

LM Unit Roots Test with two breaks

\begin{tabular}{|c|c|c|c|c|c|c|c|c|}
\hline Country & OREX & & & & BMREX & & & \\
\hline & $\mathbf{L M}$ & TB & $\mathbf{B}_{\mathrm{t} 1}$ & $B_{t 2}$ & LM & TB & $\mathbf{B}_{\mathrm{t} 1}$ & $\mathbf{B}_{\mathrm{t} 2}$ \\
\hline Algeria & $-3.170(1)$ & $\begin{array}{l}1990 \\
1993\end{array}$ & $0.589 * * *$ & $0.255 * * *$ & $-3.554(8)^{*}$ & $\begin{array}{l}1985 \\
1993\end{array}$ & -0.050 & $0.496^{*}$ \\
\hline Egypt & $-5.592(8) * * *$ & $\begin{array}{l}1985 \\
1990\end{array}$ & 0.008 & $0.609 * * *$ & $-8.850(6)^{* * *}$ & $\begin{array}{l}1983 \\
1990\end{array}$ & $-0.105 * * *$ & $0.159 * * *$ \\
\hline Iran & $-2.015(8)$ & $\begin{array}{l}1982 \\
1985\end{array}$ & $-0.802 * *$ & -0.016 & $-7.477(8)^{* * *}$ & $\begin{array}{l}1981 \\
1990\end{array}$ & $0.530 * * *$ & $0.973 * * *$ \\
\hline Iraq & $-5.890(7)^{* * *}$ & $\begin{array}{l}1990 \\
1996\end{array}$ & $0.439 * * *$ & $3.020 * * *$ & $-2.687(3)$ & $\begin{array}{l}1992 \\
1994\end{array}$ & $2.311 * * *$ & $0.890 * *$ \\
\hline Israel & $-4.383(7)^{* *}$ & $\begin{array}{l}1985 \\
1992\end{array}$ & 0.058 & $0.187^{* *}$ & $-3.121(0)$ & $\begin{array}{l}1980 \\
1984\end{array}$ & 0.119 & 0.129 \\
\hline Jordon & $-2.937(5)$ & $\begin{array}{l}1985 \\
1988\end{array}$ & $-0.219 * * *$ & $0.180 * * *$ & $-2.419(7)$ & $\begin{array}{l}1985 \\
1988\end{array}$ & $-0.158 * *$ & $0.224 * *$ \\
\hline Lebanon & $-2.925(6)$ & $\begin{array}{l}1992 \\
1996\end{array}$ & $-2.113 * *$ & 1.06 & $-2.796(2)$ & $\begin{array}{l}1991 \\
1994\end{array}$ & $0.818^{*}$ & 0.547 \\
\hline Libya & $-2.849(0)$ & $\begin{array}{l}1983 \\
1989\end{array}$ & -0.067 & -0.081 & $-4.698(1)^{* * *}$ & $\begin{array}{l}1982 \\
1986\end{array}$ & -0.011 & $0.334 * *$ \\
\hline Morocco & $-2.975(8)$ & $\begin{array}{l}1981 \\
1985\end{array}$ & -0.091 & -0.108 & $-3.567(7)^{*}$ & $\begin{array}{l}1985 \\
1987\end{array}$ & $-0.338 * * *$ & $-0.189 *$ \\
\hline $\begin{array}{l}\text { Saudi } \\
\text { Arabia }\end{array}$ & $-5.864(7)^{* * *}$ & $\begin{array}{l}1983 \\
1987\end{array}$ & 0.014 & -0.034 & $-5.619(7)^{* * *}$ & $\begin{array}{l}1985 \\
1994\end{array}$ & 0.018 & $-0.045 * *$ \\
\hline Syria & $-4.220(7)^{* *}$ & $\begin{array}{l}1986 \\
1994\end{array}$ & $-0.955 * * *$ & $2.181 * * *$ & $-3.239(7)$ & $\begin{array}{l}1981 \\
1983\end{array}$ & -0.259 & 0.007 \\
\hline Tunisia & $-3.059(7)$ & $\begin{array}{l}1992 \\
1996\end{array}$ & $0.271^{* *}$ & $0.212^{* *}$ & $-3.298(7)$ & $\begin{array}{l}1980 \\
1989\end{array}$ & -0.019 & $-0.370 * * *$ \\
\hline Turkey & $-2.925(8)$ & $\begin{array}{l}1983 \\
1986\end{array}$ & $0.390^{* *}$ & $-0.382 * *$ & $-4.719(6)^{* * *}$ & $\begin{array}{l}1981 \\
1993\end{array}$ & $0.175^{*}$ & $0.573 * * *$ \\
\hline
\end{tabular}

Notes: TB is the date of the structural break. $\mathrm{B}_{\mathrm{t} 1}$ and $\mathrm{B}_{\mathrm{t} 2}$ are the dummy variables for the structural breaks in the intercept. Critical values for the LM test at 10, 5 and $1 \%$ significance levels are $-3.504,-3.842,-4.545 . *, * * * * *$ denote statistical significance at the 10,5 and $1 \%$ levels, respectively. The lag length is reported in parentheses 
Table 4

LM Unit Roots Test with one break

\begin{tabular}{|c|c|c|c|c|c|c|}
\hline Country & OREX & & & BMREX & & \\
\hline & LM & TB & $\mathbf{B}_{\mathrm{t}}$ & LM & TB & $\mathbf{B}_{t}$ \\
\hline Algeria & ----- & ----- & ----- & $-1.906(0)$ & 1994 & -0.162 \\
\hline Egypt & $-3.157(1)$ & 1988 & -0.150 & ------ & ----- & ------ \\
\hline Iran & $-0.893(0)$ & 1992 & $2.894 * * *$ & ------ & ------ & ------ \\
\hline Israel & $-2.995(6)$ & 1984 & $0.180^{*}$ & $-2.572(0)$ & 1984 & 0.099 \\
\hline Lebanon & $-2.542(2)$ & 1994 & 0.420 & $-2.365(2)$ & 1994 & 0.486 \\
\hline Libya & $-2.610(0)$ & 1983 & -0.056 & $\begin{array}{l}-4.247 \\
(1)^{* * *}\end{array}$ & 1983 & 0.052 \\
\hline Morocco & $-2.400(8)$ & 1980 & 0.145 & ------ & ------ & ------ \\
\hline Saudi Arabia & $\begin{array}{l}-4.927 \\
(7) * * *\end{array}$ & 1987 & -0.026 & $\begin{array}{l}-4.661 \\
(7) * * *\end{array}$ & 1987 & -0.018 \\
\hline Syria & ------ & ------ & ------ & $-2.897(7)$ & 1996 & 0.306 \\
\hline Tunisia & ------ & ------ & ------ & $-2.839(8)$ & 1989 & $-\overline{0.342 * * *}$ \\
\hline
\end{tabular}

Notes: TB is the date of the structural break. $\mathrm{B}_{\mathrm{t}}$ is the dummy variable for the structural break in the intercept. Critical values for the LM test statistic at the 10,5 and $1 \%$ significance levels are $-3.211,-3.566,-4.239$. The lag length is reported in parentheses. $*$, **, $* * *$ denote statistical significance at the 10,5 and $1 \%$ levels, respectively.

Table 5

\section{LM Unit Root tests (Without Break)}

\begin{tabular}{lll}
\hline Country & OREX & BMREX \\
\hline Algeria & ----- & $-1.663(0)$ \\
Egypt & $-2.946(1)^{*}$ & ----- \\
Israel & ----- & $-2.206(0)$ \\
Lebanon & $-2.222(2)$ & $-2.085(2)$ \\
Libya & $-2.300(0)$ & $-2.933(0)^{*}$ \\
Morocco & $-2.021(1)$ & ------- \\
Saudi Arabia & $-3.891(7)^{* * *}$ & $-2.498(1)$ \\
Syria & --------- & $-2.432(7)$ \\
\hline
\end{tabular}

Notes: The 1,5 and $10 \%$ critical values for the LM test without a break are $-3.63,-3.06,-2.77$, respectively $* * *$ and $* * *$ denote statistical significance at the $10 \%, 5 \%$ and $1 \%$ levels respectively. The lag length is reported in parentheses.

\section{CONCLUSION}

Using official and black market real exchange rates data from thirteen MENA countries are examined over the period 1970-1998 to test for evidence of PPP. We utilize a LM unit root test that endogenously determines breaks in level. The mean reversion hypothesis is accepted for the four of thirteen countries using the official exchange rate and five of thirteen countries using black market exchange rate.

In this study we provide an analysis of PPP persistence by comparing a data set of BMREX and OREX for 13 MENA economies. We calculate the half life point estimates by using traditional methodology. The point estimates of the half lives for both OREX and BMREX in the seven countries are lower than range of the consensus of 3-5 years in the literature. 


\section{REFERENCES}

Abuaf, N. and Jorion, P. (1990). Purchasing Power Parity in the Long Run. The Journal of Finance, 45(1), 157- 174.

Adler, M. and Lehmann B. (1983). Deviations from Purchasing Power Parity in the Long Run, Journal of Finance. 38(5), 1471- 487.

Age'nor P.R and Taylor M.P. (1993). The causality between official and parallel exchange rates in developing countries, Applied Financial Economics, 3, 255-266.

Aslan, A., Kula, F. and Kalyoncu, H. (2010). Additional evidence of long-run purchasing power parity with black and official exchange rates, Applied Economics Letters, First published on 28 September 2009 (iFirst) URL:http://dx.doi.org/10.1080/13504850902967522

Baghestani H. (1997). Purchasing power parity in the presence of foreign exchange black markets: the case of India, Applied Economics, 29, 1147-1154.

Baharaumshah, A. and Ariff, M. (1997). Purchasing power parity in South East Asian countries economies: A cointegration approach, Asian Economic Journal, 11(2), 141-153

Bahmani-Oskooee, M. and Goswami, G. G. (2005). Black Market Exchange Rates and Purchasing Power Parity in Emerging Economies, Emerging Markets Finance and Trade, 41, $37-52$.

Bahmani-Oskooee, M. (1998) Do exchange rates follow a random walk process in Middle Eastern countries? Economics Letters, 58, 339-344.

Bahmani-Oskooee, M., and Mirzai, A. (2000). Real and Nominal Effective Exchange Rates for Developing Countries: 1973:1-1997:3, Applied Economics, 32, 411-428.

Basher, S. A. and M. Mohsin, (2004). PPP tests in cointegrated panels: evidence from Asian developing countries, Applied Economic Letters, 11, 163-166.

Cerrato M, Sarantis N. (2007). Does Purchasing Power Parity Hold in Emerging Markets? Evidence From a Panel of Black Market Exchange Rates, International Journal of Finance and Economics, 12, 427-444.

Chen, B. (1995). Long-run purchasing power parity: evidence from some European monetary system countries, Applied Economics, 27, 377-83.

Cheung, Y.W, and Lai, K. (1993). Long-run purchasing power parity during the recent float, Journal of International Economics, 43, 181-192

Cheung, Y.W., and Lai K. (1998). Parity Reversion in Real Exchange Rates During the PostBretton Woods Period, Journal of International Money and Finance, 17, 597-614. 
Diamandis P. F. (2003). Market efficiency, purchasing power parity, and the official and parallel markets for foreign currency in Latin America, International Review of Economics and Finance, 12, 89-110.

Edwards, S. (1989). Real Exchange Rates, Devaluation, and Adjustment: Exchange Rate Policy in Developing Countries. The MIT Press: Cambridge, 87-127.

Feridun, Mete (2005). Can We Explain the Long-Term Real Equilibrium Exchange Rates through Purchasing Power Parity (PPP): An Empirical Investigation (1965-1995), Ekonomický Casopis, 53(3), 273-283.

Frankel, Jeffrey A. (1986). International Capital Mobility and Crowding-out in the U.S. Economy: Imperfect Integration of Financial Markets or of Goods Markets? in How Open is the U.S. Economy? R. W. Hafer, ed. Lexington, Mass.: Lexington Books, 33-67.

Frenkel, Jacob A. (1981). The Collapse of Purchasing Power Parity During the 1970s, European Economic Review. 16(1), 145-65.

Frenkel, J and M Mussa (1985). Asset Markets, Exchange Rates and the Balance of Payments, Handbook of International Economics, Volume II (eds.), Ronald Jones and Peter Kenen, North Holland, Amsterdam, 679- 747.

Froot, Kenneth A. and Kenneth Rogoff (1995). Perspectives on PPP and Long-Run Real Exchange Rates, In Handbook of International Economics, Volume 3, ed. G. Grossman and K. Rogoff. Amsterdam: Elsevier Science, 1647-1688.

Glen, J. (1992). Real exchange rates in the short, medium, and long run, Journal of International Economics, 33, 147-166

Hakkio, Craig S., 1986, Does the exchange rate follow a random walk? A Monte Carlo study of four tests for a random walk, Journal of International Money and Finance, 5, 221-229.

Hung, M. and Jan, Y. (2002). Use of deviations of purchasing power parity and interest rate parity to clarify the 1997 Asian financial crisis, Review of Pacific Basin Financial Markets and Policies, 5, 195-218.

Kuo, B. and A. Mikkola (1999). Re-Examining Long-Run Purchasing Power Parity, Journal of International Money and Finance, 18, 251-66.

Lee, J., Strazicich, M. C. (2003). Minimum LM unit root test with two structural breaks, The Review of Economics and Statistics, 85, 1082-1089.

Lee, J., Strazicich, M. C. (2004). Minimum LM Unit Root Test with One Structural Break. Department of Economics, Appalachian State University Working Paper Series.

Lothian, J. R. and Taylor M. (1996). Real Exchange Rate Behavior: The Recent Floar From the Perspective of the Past Two Centuries, Journal of Politzcal Economnj. 1043, 488-509. 
Lothian, J. R. and Taylor, M. P. (1997). Real exchange rate behavior, Journal of International Money and Finance, 16, 945-54.

Luintel K. B. (2000). Real Exchange Rate Behaviour: Evidence from Black Markets, Journal of Applied Econometrics, 15, 161-185.

MacDonald, R (1996). Panel unit root tests and real Exchange rates, Economic Letters, 50, 7 11.

Mark, N. (1990). Real and Nominal Exchange Rates in the Long Run: An Empirical Investigation, Journal of International Economics 28 1- 2, 115-36

Mark, N. (1995). Exchange Rates and Fundamentals: Evidence on Long-Horizon Predictability, American Economic Review, 85, 201-218.

Meese, R and K. Rogoff. (1983). Empirical Exchange Rate Model of the Seventies: Do They Fit out of Sample?, Journal of International Economies, 14, 2-24

Montiel, P. (1997), "Exchange rate policy and macroeconomic management in ASEAN countries: in J. Hicklin et al.: Macroeconomic issues facing ASEAN countries, Washington, $\mathrm{DC}, \mathrm{IMF}$.

Narayan K. and B.C. Prasad (2005). The validity of purchasing power parity hypothesis for eleven middle eastern countries, Review of Middle East Economics and Finance 3, 135-149.

Perron, P. (1989). The great crash, the oil price shock, and the unit root hypothesis. Econometrica, 57, 1361-401.

Phylaktis K, Girardin E. (2001). Foreign exchange markets in transition economies: China, Journal of Development Economics, 64, 215-235.

Phylaktis K, and Kassimatis Y. (1994). Does the real exchange rate follow a random walk?, Journal of International Money and Finance, 13, 476-495.

Pippenger, J. (1982). Purchasing Power Parity: An Analysis of Predictive Error, Canadian Journal of Economics, 15, May, 335-346.

Reinhart C.M, and Rogoff K. (2004). The modern history of exchange rate arrangements: a reinterpretation, Quarterly Journal of Economics, CXIX, 1-48

Rogoff, K. (1996). The purchasing power parity puzzle, Journal of Economic Literature, 34, 647-68.

Roll, R., 1979. "Violations of Purchasing Power Parity and their Implications for Efficient International Commodity Markets," in International Finance and Trade, Volume 1. M. Sarnat and G.P. Szego, eds. Cambridge. Mass.: Ballinger, pp. 133-76. 
Sarno, L. (2003). Nonlinear exchange rate models: a selective overview, Rivasta di Politica Economica, 93, 33-46.

Sarno, L. and Taylor, M.P. (2002). Purchasing power parity and the real exchange rate, IMF Staff Papers, 49, 65-105.

Schmidt, P. and Phillips, P. C. B. (1992). LM tests for a unit root in the presence of deterministic trends, Oxford Bulletin of Economics and Statistics, 54, 257-87.

Taylor, M. P., (1988). An empirical examination of long run purchasing power parity using cointegration techniques, Applied Economics, 20, 1369-1381.

Taylor, M.P. and D.A. Peel (2000). Non-linear Adjustment, Long-run Equilibrium and Exchange Rate Fundamentals', Journal of International Money and Finance, 19, 33-53.

Telatar, E. and Kazdagl1, H. (1998). Re-examine the long-run purchasing power parity hypothesis for a high inflation country: the case of Turkey 1980-93, Applied Economics Letters, 5, 51-53.

Weliwita, A. (1998). Cointegration tests and the long-run purchasing power parity: Examination of six currencies in Asia, Journal of Economic Development, 23(1), 103-115.

\section{REEVALUACIJA PARITETA KUPOVNE MOĆI U MENI: EMPIRIJSKI DOKAZI U PRISUSTVU ENDOGENO ODREĐENIH PRIJELOMNIH TOČAKA}

\section{Sažetak}

Ovaj rad ponovno proučava hipotezu pariteta kupovne moći u kojoj su endogeno određene prijelomne točke ugrađene u 13 najvećih zemalja MENA-e koristeći službene tečajeve i tečajeve na crnom tržištu za period od 1970 do 1998. Koristili smo Lagrange Multiplier test jediničnog korijena koji endogeno određuje strukturalne prekide u razini. Nalazimo dokaze pariteta kupovne moći za osam od trinaest zemalja na razini od $10 \%$ ili bolje. Također smo konstruirali poluživote kako bismo istražili postojanost devijacija od pariteta kupovne moći. Procjene parametara poluživota za OREX i BMREX u sedam su zemalja niže od u literaturi općeprihvaćenih 3-5 godina.

Ključne riječi: PPP (paritet kupovne moći), tečaj na crnom tržištu.

JEL: E24 